\title{
Arte y desobediencia civil
}

\author{
Art and civil disobedience
}

\section{Resumen}

El arte ha permitido colocar en el debate público cuestiones políticas, ha roto esquemas convencionales, ha cuestionado la construcción de la sociedad y se ha manifestado para protestar y denunciar. Podemos observar en autores como Goya, Picasso y Rivera su inconformidad por la guerra, la pobreza y la desigualdad, y en autores como Chagall y Rothko un llamado a la conciencia y la reflexión.

De esta manera, éste artículo hace un breve repaso por las obras de pintura de una selección de autores, destacando el arte como un instrumento pacífico que conduce a la reflexión, que crítica e introduce transformaciones en las mentalidades. Igualmente, se señalan los debates políticos suscitados en la época del artista y su contribución a la transformación política, convirtiendo el arte en una invitación sublime a desobedecer civilmente.

Palabras clave: arte, desobediencia civil, política, protesta, crítica y pacifismo.

\section{Abstract}

Art has made it possible to place political matters in the public debate, has broken conventional schemes, has questioned the way society is structured and has been present to protest and denounce. In artists like Goya, Picasso and Rivera we can see their opposition to war, poverty and inequality, and in painters like Chagall and Rothko a call to awareness and reflection

This article gives a brief overview of the paintings of selected artists, emphasizing art as a pacific instrument that leads to reflection, critiques and introduces transformations of mentalities. It also discusses the political debates raised in the artists' period and his or her contribution to political transformation, making art a sublime invitation to disobey civilly.

Keywords: art, civil disobedience, politics, protest, critique and pacifism.

1 Gilma Liliana Ballesteros Peluffo es Candidata a PH.D en Estudios para la Paz, de la Universidad de Granada (España), Politóloga de la Pontificia Universidad Javeriana, elabora su tesis doctoral sobre Desobediencia Civil, producto de lo cual es el presente artículo. Se ha desempeñado como Asesora del Gobierno Nacional y docente universitaria, actualmente es la Coordinadora del Observatorio de Infancia, Adolescencia y Familia - Instituto Colombiano de Bienestar Familiar - ICBF-. 


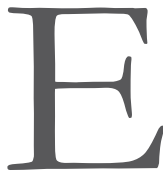

1 arte, en el sentido más holístico de la palabra, alberga en sí mismo toda la potencialidad de ser una sublime expresión y quizás la más bella expresión de desobediencia. ¿Acaso existe una forma más pacífica de desobedecer? Este artículo no pretende realizar un recorrido político por la historia del arte, pero sí reclama atención sobre cómo éste puede convocar cambios sociopolíticos profundos, hacer protesta, e introducir nuevas formas de pensamiento, haciendo clásica la vanguardia en un inacabado proceso de transformación y cambio.

Como el arte permite contemplar -lo hasta entonces no digno de contemplación- puede ser la mejor excusa para pensarnos como ciudadanos frente a unas leyes que nos rodean, que se han erigido en algunas ocasiones sin consultarnos o en nombre de nuestra ciudadanía por autoproclamados representantes de nuestros intereses, a veces, inconscientes de los alcances que pueda tener la ley o por fuera de nuestra comprensión y, por lo tanto, de nuestra conciencia.

Es imaginable, entonces, que una obra de arte que critica el menosprecio por la vida, deje reflexionando al observador con una amarga sensación de miseria, incluso sobre su propia existencia, delirando que él mismo es despreciado por alguna condición. El arte es y puede ser un instrumento de sensibilización de la realidad, un llamado a la conciencia, una reflexión sobre nuestra postura frente a la realidad socio-política. Ese observador podría llegar a casa para objetar la pretensión de aprobar penas de muerte a condenados, rechazar las políticas de salud que anticipan la muerte anunciada de un enfermo terminal y promover políticas públicas de inclusión a personas en condición de discapacidad.

Hay quienes se estremecen de emoción pensando, lo que logra un juego de colores sobre un lienzo, las palabras coordinadas con un ritmo, unas letras narrando una historia, el simple diseño de unas paredes en medio del vasto paisaje, el tiempo detenido en la fotografía, la representación de los personajes sobre unas tablas, la forma visual de contar la historia, y tantas formas de expresarnos que logran hacer efectivamente cambios en las más variadas mentalidades.

Sólo el arte podría tener como norma fundamental no tener reglas que obedecer estrictamente. Por el contrario, debe romperlas, desobedecerlas conscientemente como parte del proceso creativo. No reproducir lo hecho, sino avanzar. Generalmente, cuando se le ha impuesto leyes al arte, inevitablemente, resulta un artista que prescindiendo de ellas logra trascender. En el arte como en otras ciencias o disciplinas, el conocimiento a medias no sólo es propio del mediocre sino del esnobista.

Si bien el arte es la expresión que goza de mayor libertad, irreverente y casi anárquica, no es cualquier cosa, porque cualquier cosa no puede obtener un carácter sublime, ni argumentar la profundidad de un relato que es lo que pretende ser en sí mismo una obra de arte. Las obras contienen un sentido, así como las ideas políticas. En el arte, la discusión ha girado en torno al concepto 
de belleza, a la búsqueda de imitar fidedignamente la naturaleza (Renacimiento) y a la expresión de lo tangible e intangible (nuevos movimientos); mientras que en política la discusión ha girado sobre conceptos capitales que nos dotan de identidad: naturaleza humana, libertad, justicia, derechos y formas de gobierno. Esta es la razón por la cual ninguna idea, ni obra de arte, puede ser cualquier cosa: son esencialmente semánticas.

Sumergirse en ese vasto mundo del arte implica correr el riesgo de no salir nunca de allí y dejar inacabada esta disertación, por lo tanto, como exigencia científica de investigación, limitaremos intencionadamente el artículo a breves descripciones de momentos de la vida y obra de una serie de artistas, todos ellos pintores que convocan la reflexión política, la conciencia y nuestro protagonismo en la construcción del devenir. La selección de los autores ha sido arbitraria, algunos de ellos de insigne categoría quedarán sin mencionar, lo cual implica una valiosa oportunidad de seguir escudriñando en el arte el valor de la reflexión, la expresión y la política.

La historia sirve como excusa metodológica para llevar un orden cronológico en la observación del arte como instrumento de la noviolencia y específicamente de la desobediencia. Así, podemos advertir con claridad que la ruptura con el Medioevo llevó a los artistas a reflexionar sobre el estilo, romper con la tradición y buscar una identidad en las posibilidades. La vuelta al antropocentrismo trajo la posibilidad de pensarse. Esa posibilidad de pensarse implicó la obsesión de revelar, contar, narrar o decir en el lienzo, todo lo que estaba sucediendo, iniciándose, entonces, una tendencia en el arte por demostrar la realidad y la verdad, pasando del sentido sublime al sentido "real" o "científico" de las cotidianidades. Hubo un consenso sobre paisajes, retratos y trabajos cotidianos, tratando de conservar ese llamado del arte por expresar el sentido de lo bello y del placer.
Justo en este momento histórico del arte un autor como Caravallo desobedece este consenso, para hacer del arte un instrumento que enseña descarnadamente lo real, el arte que denuncia, que cuenta, que protesta, pero especialmente que muestra ese lado también infinitamente humano: la injusticia, la violencia, la perversión.

En esta misma época Francisco Vittoria (14831546), Juan de Mariana (1536-1624) y Francisco Suárez (1548-1617), religiosos dominicos y jesuita respectivamente, planteaban que el límite de la obediencia a las leyes se encontraba en la conciencia misma del individuo por la justicia, por lo que cualquier acción que no vaya según la conciencia es el verdadero pecado. Estas ideas contribuyeron al desarrollo de las ideas liberales, pero, especialmente, liberaron al creyente de una dualidad entre fe y ciudadanía.

Así, arte y política se encuentran para plantearse bases epistemológicas de la relación moral del individuo con lo público: la ética, la deliberación, la expresión, la inclusión y la visibilidad de la miseria humana expuesta por la violencia, la pobreza, la corrupción y la dominación.

Las ideas liberales desarrolladas en la época de la Ilustración constituyeron la base ideológica de la Revolución Francesa, cuya pretensión fue instaurar un nuevo régimen político que recogiera las ideas políticas de Rousseau, Voltaire y Montesquieu, entre otros pensadores. Los cuestionamientos a la monarquía absolutista se hacían desde diferentes oficios. Desde los campesinos que sufrían las consecuencias de la pobreza y la crisis agrícola, hasta los artistas como Goya, quien ya había pintado su colección Caprichos, una crítica social con una técnica nueva de estampas en aguafuerte, en una sátira a la sociedad de su época, ilustrando la pobreza, la codicia de los sacerdotes de la iglesia, la violencia contra las mujeres, la violencia en la educación a los niños y la Inquisición ${ }^{2}$. Una vez estalla la Revolución Francesa, Goya se encuentra en una situación

2 Véase colección Caprichos publicada en 1799, especialmente las siguientes obras: Que se la llevaron (Capricho Nº 8), Están Calientes (Capricho No 13), Aquellos Polvos (Capricho N²3), No hubo remedio (Capricho N²4), Si quebró el cántaro (Capricho $\left.N^{\circ} 25\right)$, Mucho hay que chupar (Capricho No 45), todos de 1797-1798. 
contradictoria: como liberal ilustrado desea que las ideas de la Revolución Francesa imperen, pero rechaza la violencia de los ejércitos napoleónicos. Sus pinturas muestran el horror de la tortura, los asesinatos y las violaciones. Son imágenes carentes de perdedores y de vencedores, sólo recrea a los hombres en el caos de la violencia, perdiendo la investidura de ciudadanos ilustrados.

La Revolución Francesa no sólo permitió evidenciar cuestiones sociales o políticas, de manera cruda y descarnada, sino que: "los artistas se sintieron libres para elegir como tema desde una escena shakespeariana hasta un suceso momentáneo; cualquier cosa, en efecto, que les pasara por la imaginación o provocara su interés" (Gombrich, 1995, p. 482). Esto muestra el alcance de las ideas liberales.

Uno de los temas de interés de algunos artistas de la época, que suscitó polémicas, fue el de recrear acontecimientos históricos de relevancia política, como la de Jhon Singleton Copley, en 1785, que nominó: Carlos I exigiendo la entrega de los cinco miembros inculpados de la Cámara de los Comunes, suceso de 1641 y que le implicó al autor la investigación de los hechos para lograr una ilustración lo más fidedigna posible. Cuatro años más tarde, dicha pintura se reprodujo en Francia y sirvió como alusión de las diferencias entre el rey y los representantes del pueblo.

De ésta forma, la Revolución Francesa trae para el arte la posibilidad ilimitada de expresarse: "éste es el efecto más destacado de la ruptura de la tradición: los artistas pasaron a sentirse en libertad de plasmar sus visiones sobre el papel como sólo los poetas lo habían hecho hasta entonces" (Gombrich, 1995, p. 488). Aún en la plena libertad de expresión, el arte siguió cuestionando las reglas, dirigiéndose a lo político y llamando la atención sobre los hechos que causan injusticia, violencia o exclusión.

La primera preocupación de la academia es distinguir entre lo que verdaderamente puede $y$ debe considerarse arte y el mero oficio del artesano, lo cual inevitablemente condujo a la academia a colocar determinadas reglas y conformar unas élites que "pudieran" y "supieran" distinguir lo bello de lo ordinario. Entonces, en medio de ese mundo de posibilidades, surgen las diferencias, las disputas y luego las exclusiones. Así, irónicamente, durante el siglo XIX cuando se posicionan las ideas liberales, la reivindicación del individuo, como autónomo, consciente y libre, es la época de mayor visibilización de la exclusión y la dominación. La Revolución Industrial provocó una relación difícil entre el artista y el público: "mientras para el hombre de negocios, un artista era poco más que un impostor que pedía precios absurdos por algo que apenas podía considerarse como un trabajo honrado" (Gombrich, 1995, p. $502)$, entre los artistas había quienes condescendientes con el cliente dibujaban lo que se les pedía y quienes en un acto radical de reivindicación por el gusto, manifestaron su total desprecio por los convencionalismos, entre estos también hubo quienes se declararon genios por el mero hecho de no encontrar compradores.

Esta no era sólo realidad de los artistas, la Revolución Industrial trajo consigo, además del desarrollo tecnológico, consecuencias sociales que cuestionaron las ideas liberales, como la justificación del mantenimiento de las colonias en África, América y Asia, la defensa de la esclavitud, la explotación desmedida de recursos naturales y la explotación de la mano de obra. En medio de ese panorama, el pintor francés Courbet (1819-1877) escribió: "Confío siempre ganarme la vida con mi arte sin tener que desviarme nunca de mis principios ni el grueso de un cabello, sin traicionar mi conciencia, ni un solo instante" (Gombrich, 1995, p. 511), creando lo que conoceríamos como el movimiento realista, cuyo deseo era pintar la verdad por encima de la belleza. El arte no debía servir como anestesia, sino como expresión real de lo que acontecía.

Luego Edouard Manet (1832-1883) y Claude Monet (1840-1926), conscientes de la libertad, serían los precursores de lo que conocemos como el movimiento impresionista, los cuales, cuestionando los convencionalismos e incluso el realismo de Courbet, se dedicaron a comprobar que la representación del hombre debía hacerse 
sin condiciones artificiales, por lo tanto, debía pintarse de acuerdo a lo que veían nuestros ojos y no a ideas preconcebidas. Por primera vez se retrató la percepción de manera consciente. En la concepción de la desobediencia civil, la conciencia es un elemento crucial, ya que implica el conocimiento no sólo de sí mismo, sino de cada una de las acciones del individuo.

Esa individualidad se vio recreada por Paul Cézanne (1839-1906), Vicent Van Gogh (18531890) y Paul Gauguin (1848-1903), quienes inspirarían el cubismo, el expresionismo y el primitivismo, cuyo desarrollo significaba la posibilidad de navegar en el inconmensurable mundo de las posibilidades de la expresión, donde todas y cada una de ellas podría ser respetada como manifiesto de la individualidad o como protesta por la inconformidad. Esto comprende la facultad de llamar la atención sobre la injusticia de manera creativa, pacífica y responsable.

Los expresionistas sintieron tan intensamente el sufrimiento humano, la pobreza, la violencia y la pasión que se inclinaron por creer que la insistencia en la armonía y la belleza en el arte sólo podían nacer de una renuncia a ser honrado [...] ellos querían [...] expresar su compasión por los deseheredados y los contrahechos (Gombrich, 1995, p. 567).

Al tiempo que se desarrollaba el movimiento expresionista, también surgió de la mano de Henri Matisse (1869-1954), y su obsesión por la libertad en el color, el fawismo, de la denominación francesa fanves -fieras salvajes o salvajes-, que le permitiría posteriormente al arte latinoamericano encontrar su propia identidad en los colores propios del continente y la expresión de lo autóctono. Así, el muralista mexicano Diego Rivera podría llevar su obra de campesinos, trabajadores, indígenas, con los colores de la tierra, a los muros de las entidades y edificios.

Marc Chagall (1887-1985) y Mark Rothko (1903-1970), más contemporáneos, también tuvieron el objetivo de plasmar la verdad como se veía ante sus propios ojos. Rothko quiso llamar la atención sobre la tragedia y la brutalidad, que el público, en vez de extasiarse con la belleza del cuadro, sintiera repulsión por esa parte del hombre asociada a la violencia y a la miseria. Chagall, por su parte, víctima de la violencia política de su época (Primera Guerra Mundial, la Revolución Rusa y la persecución judía), dejó plasmada en su obra el arte popular, la vida cotidiana del campo y la ciudad, lo simple que no se contagia, lo sencillo que se funde con el sentido. Mientras que la vida y obra de Frida Kahlo nos introduce al complejo triangular de feminismo, política y expresión.

El arte desobediente es una de las formas como los seres humanos podemos manifestarnos en desacuerdo conscientemente sobre asuntos comunes, que cuestiona no sólo las reglas, sino que invita a la reflexión, el pensamiento, el sentido y el lenguaje, y que ciertamente tiene un impacto político. Desafiar las reglas del arte como oficio, de ninguna manera es en sí mismo una desobediencia civil; pero el arte es un excelente medio para desobedecer civilmente, llamar la atención sobre la necedad de la violencia y la injusticia. El arte como revelador de la historia, como denunciante de las atrocidades de la violencia, el autoritarismo y de la inconsciencia. El arte como movilizador de la relación moral del individuo con lo público. El arte como influencia en la transformación política y la evolución de las democracias.

Arte desobediente es, entonces, un vehículo -el más bello- para desobedecer pacíficamente y generar cambios deseables en materia de justicia, inclusión, convivencia y respeto por la diferencia. El arte como instrumento de la noviolencia es, pues, lo que interesa en este breve artículo.

\subsection{Michelangelo Merisi de Caravaggio (1571-1610): La fuerza de la verdad}

¿Por qué Caravaggio podría representar la desobediencia civil?, ¿'Por qué siendo un hombre agresivo, malhumorado y prófugo de la justicia por homicidio, podría romper pacífica y sublimemente con las reglas? ¿Cuál es la relación entre la vida de Caravaggio y la desobediencia civil? 
Ciertamente ninguna. La vida de Caravaggio no tiene ningún aspecto que pueda relacionarse con la desobediencia civil. Violó las reglas de la ciudad, acató las reglas de la calle (duelo con espadas) aparentemente en contra de su propio fuero moral; inmerso en la dualidad del arrepentimiento y su obstinación por las peleas y las riñas callejeras. Pero su obra es toda una oda desobediente, una expresión visceral que cuestiona, crítica y protesta, una muestra cruda de la perversión y morbosidad alrededor de la carne y la violencia.

Por primera vez en la historia irrumpe un artista que provoca con sus cuadros repugnancia por la forma como muestra la agresión física desmedida sobre la humanidad, haciendo que el observador cuestione la violencia, reflexione sobre su permisividad sobre actos que causan horror. El autor no sólo quería revelar la realidad, sino que desalojó la belleza de sus cuadros, para mostrarnos que el verdadero rostro de la piel y la carne expresan sentimientos lascivos, pero infinitamente humanos.

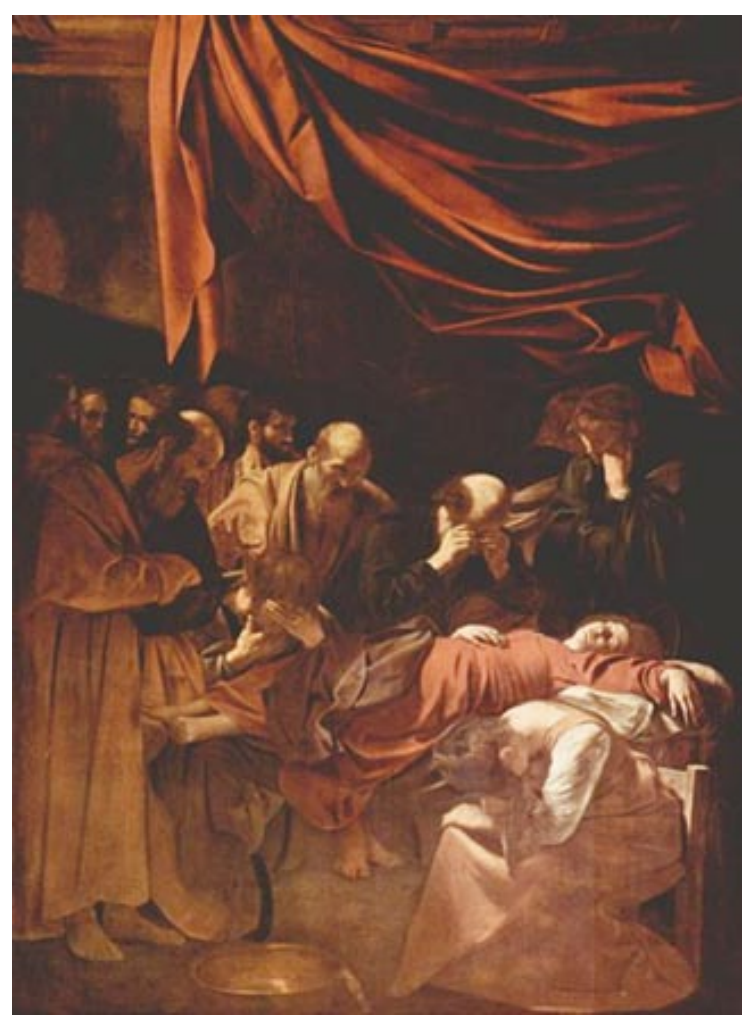

Muerte de la Virgen. 1606.
Caravaggio pinta las carnes. En Muerte de la Virgen (1606) un rostro de María pálido en brazos de la muerte. El dolor de los apóstoles por su muerte, a pesar de su creencia en la resurrección. Logra retratar una tristeza sórdida, temerosa pero real. En la pintura está también María Magdalena con la cabeza inclinada, aunque no puede verse su rostro, puede percibirse su llanto por la muerte de María. El cuadro La incredulidad de Santo Tomás muestra con mucho mayor impacto al apóstol introduciendo el dedo en la herida de Jesús, cuyo tono amarillento de su cuerpo y la carne maleable nos muestra que se encuentra muerto y no tiene ya ningún dolor.

La pintura de Caravaggio carnal y sangrienta nos recuerda lo infinitamente humanos que son sus sujetos pictóricos. Presenciamos los sentimientos desgarrados, la crueldad de la violencia -incluso religiosa-, del ostracismo y del miedo. Lejos de los ángeles en el cielo, de la resurrección y la vida eterna, Caravaggio intestinalmente recuerda la violencia, la sevicia, el dolor y la impotencia. Y esta desobediencia, la desobediencia artística, permite recordarnos como humanos, permite recordar al Dios humano, al Dios que tuvo carne, a la María terrenal, pálida y muerta, y la cara de dolor y terror de los cercanos apósteles y la Magdalena.

Su pintura hiperrealista cuestiona la subliminidad religiosa sobre los protagonistas. Una Judith sin ninguna muestra de compasión por el temible Holofernes -evento retratado no sólo por Caravaggio, sino también por Boticelli, Carraci, Giordano y hasta Goya-, donde se muestra a Judith como una heroína del pueblo israelita y su triunfo sobre los crueles asirios. Representa la capacidad de la mujer, que seduce y asesina por su pueblo. Pero Caravaggio destaca la falta de compasión y arrepentimiento de Judith sobre su víctima, por tratarse de un ser cruel, del representante de un pueblo que somete y domina a los israelitas. La mujer que también puede ser cruel y viril, la mujer que justifica la muerte ante la dominación del tirano. Caravaggio hizo también pinturas de los creyentes pobres, de los peregrinos y de los fie- 


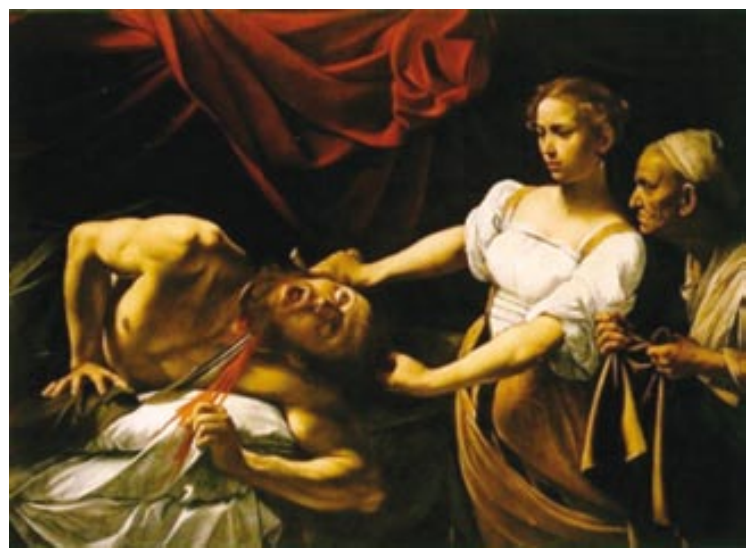

Judith y Holofernes. 1598.

les, en la calle, con los pies descalzos. Utilizó a las prostitutas para que le sirvieran de modelo para pintar a la virgen, de lo cual surgieron unas Marías más terrenales, descubriendo la humanidad de Dios, cuestionando la belleza religiosa, motivando la inclusión del excluido en los pasajes bíblicos. En sus cuadros encontraremos casi siempre unos observadores tradicionales de la cotidianidad de su época: ancianos reverentes, jóvenes temerosos, verdugos sin piedad, clérigos cuestionándose, agiotistas, jugadores de cartas o trabajadores concentrados en levantar la cruz de San Pedro.

Precisamente llama la atención en la obra La crucifixión de San Pedro la representación de una verdad detestable: la cotidianidad de los tres romanos concentrados en levantar la pesada cruz del santo, desprovistos de reflexión y concentrados únicamente en la labor encomendada, como si se tratase de una cuestión banal: la condena, la muerte, el ejercicio de la violencia, la persecución política, la persecución cristiana. Ahí retrata el rostro de los otros (los verdugos), unas personas comunes y corrientes, las cuales se limitan hacer su trabajo, inconscientes del significado de éste en el marco del despotismo de Nerón, convencidos de estar haciendo lo correcto: obedecer, sin la más mínima expresión de consciencia sobre su quehacer, ni para defenderlo ni para reprocharlo. Un llamado de atención a la consciencia sobre nuestros actos, sobre nuestro trabajo, sobre lo que permitimos, sobre lo que aprobamos sin consciencia.
Esa muestra descarnada de las expresiones humanas, de la visibilidad de la carne, la exaltación de la gente cotidiana como protagonistas en la historia de Dios, la crudeza de la violencia ejercida por los mismos humanos, pero especialmente, la invitación a pensar, hacen de la obra de Caravaggio una contribución a la reflexión moral sobre lo que permitimos como ciudadanos a la política o a la religión; sobre lo que nos permitimos nosotros mismos como individuos, violentando nuestra propia autodeterminación, nuestra propia moral. Una desobediencia sobre los parámetros del arte que nos acercaron a una realidad histórica mucho más realista.

Sobre la vida de Caravaggio pueden existir muchos cuestionamientos. Reconocido como un ser agresivo y malhumorado, presentaba una contradicción: mientras pintaba para espantarnos frente a la capacidad misma del humano con sus alcances en materia de violencia, él mismo era un ser violento. No obstante, en su trágica autoconciencia revela su pecado y pide perdón a través de la pintura, particularmente en un autorretrato, donde está él mismo decapitado, David con la cabera de Goliat (1607). En la obra se mues-

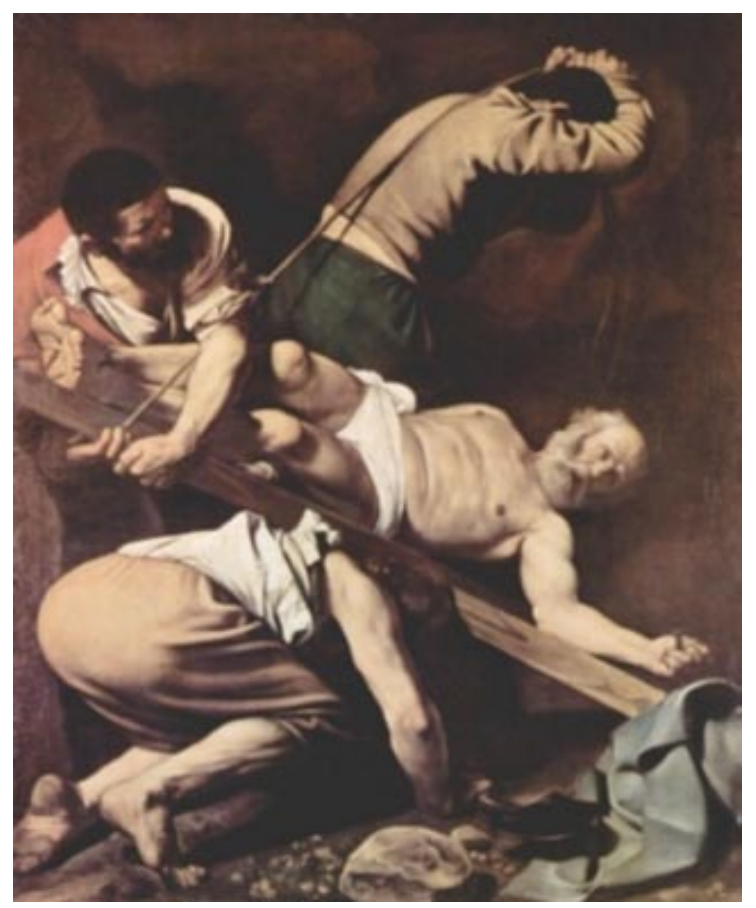

La crucifixión de San Pedro. 1601. 
tra un David sosteniendo la cabeza de Goliat con cierto asco, interpretada como la propia repulsión por sus actos y en la espada está tallada unas letras que dice: "La bumildad mata el orgullo". Caravaggio quiso controlar y redimir su propia violencia a través de la pintura, pero no logró contralarla ni redimir su vida de prófugo y asesino.

El reconocido historiador del arte Simon Schama afirma: "Para mí la fuerza de su arte es la fuerza de la verdad; la fuerza de la verdad inclusive de nosotros mismos como humanos, la redención por la confesión, reconocer que somos David y Goliath" (Schama, 2006), afirmación que no está lejos de los principios de la noviolencia planteados por Gandhi. Descubrir la fuerza de la verdad, el reconocimiento y la reflexión que como humanos nos lleva a reconocer en la violencia la destrucción de todo y la imposibilidad de ser, en su sentido ontológico.

\subsection{Francisco de Goya (1746-1828): Los desastres de la guerra}

Sin duda, vivir y visualizar las consecuencias de la violencia marca la vida de cualquier individuo. Goya, cuya única pretensión era alzarse como un pintor excepcional, tuvo que presenciar, no sólo la violencia ejercida por la iglesia en el marco de los actos de la Inquisición que persistía aún en España en la segunda mitad del siglo XVIII, sino la violencia cometida por los ejércitos de Napoleón, defendiendo los "nobles" ideales liberales, en una clara contradicción entre pensamiento y acto.

Aún cuando estemos de acuerdo con los fines, la anulación que trae la violencia nos hace cuestionar los medios y quizá eso fue lo que le sucedió a Goya. Ese cuestionamiento sobre los medios es lo que convoca la irenología. Si bien podemos encontrar un consenso más o menos generalizado sobre la lucha contra el terrorismo, la consolidación de las democracias, la lucha con-

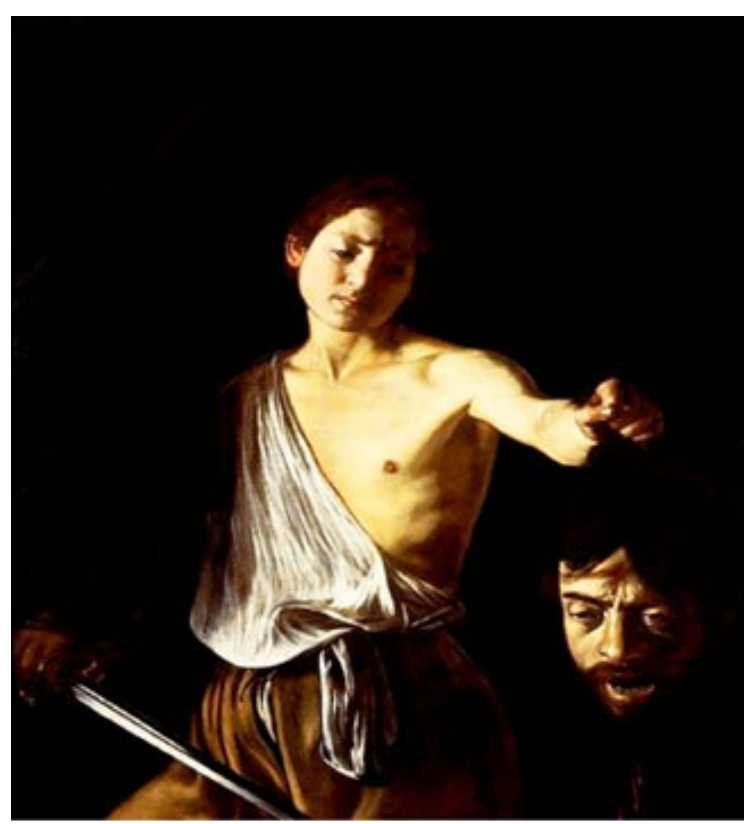

David con la cabeza de Goliat. 1607.

tra el tráfico de drogas, el respeto por la diferencia, entre otras, son los medios, especialmente los medios violentos, los que se ponen en cuestión. Goya declaró en el Diario de Madrid del 6 de febrero de 1779 que la colección de grabados "Caprichos" son "una censura a los errores y vicios humanos [...] extravagancias y desaciertos que son comunes en toda sociedad civil" (Rose \& Hagen, 2005, p. 35). Caprichos es una serie de grabados de pequeño formato en el cual recreó escenas de violencia contra las mujeres, herejes llevados a juicio por la Inquisición, clérigos codiciosos, la violencia contra los niños en el sistema educativo, los matrimonios por conveniencia, nobles representados por burros, como una pesada carga que lleva el pueblo llano. Brujas, duendes y monstruos.

Podemos destacar algunos grabados que hacen parte de la colección. Para ilustrar la crítica de Goya a la sociedad de su época y especialmente a la violencia, Capricho 8, Que se la llevaron, muestra una mujer que es atacada por un hombre vestido de monje; Capricho 12, A la caza de dientes, retrata una mujer saqueando los dientes

3 La obra se encuentra en el Museo del Grabado de Goya, en Zaragoza, España. 


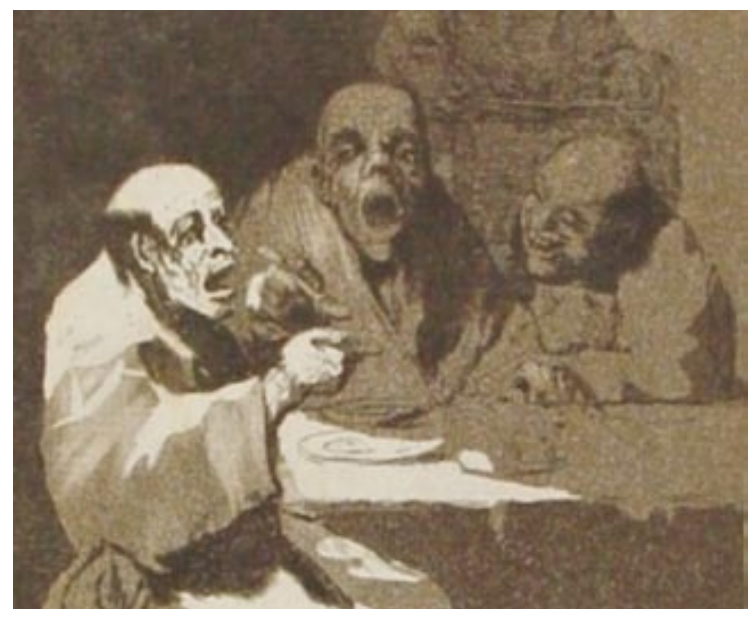

Capricho 13, Están Calientes.

de un muerto que cuelga a pesar de su terror por el cadáver, mostrando la codicia; Capricho 13, Están Calientes, quiere retratar la codicia de los clérigos quienes acuñaban una enorme fortuna en discordancia con la mayoría del pueblo llano, quien vivía en una profunda carestía; Capricho 23. Aquellos Polvos, suscitó que se le denunciara ante la Inquisición, por tratarse de una crítica al jurado inquisidor.

Capricho 24, No bubo Remedio, una clara alusión a la Inquisición, donde una mujer es llevada hacia su sentencia de muerte; Capricho 25, Si quebró el cántaro, donde un clérigo golpea a un niño como parte de la educación impartida. Capricho 39, Hasta su abuelo, retrata a un hidalgo con cabeza de burro, un cuestionamiento a una nobleza que había perdido sus propiedades, pero que se jactaban del título nobiliario y se negaban a trabajar; Capricho 45, Mucho bay que chupar, unas brujas con aspecto exageradamente maléfico; Capricho 52, Lo que puede un sastre, un árbol con una túnica cuya apariencia es la de un fraile con los brazos extendidos, ante el cual cae una mujer de rodillas para rezar, intentando burlarse de lo que puede hacer un hábito.

El mundo de las brujas le sirvió a Goya para denunciar la degradación del ser humano, cuyas facciones se alteran incluso, convirtiéndose en mascaras animalescas en las "brujas" más perversas; y

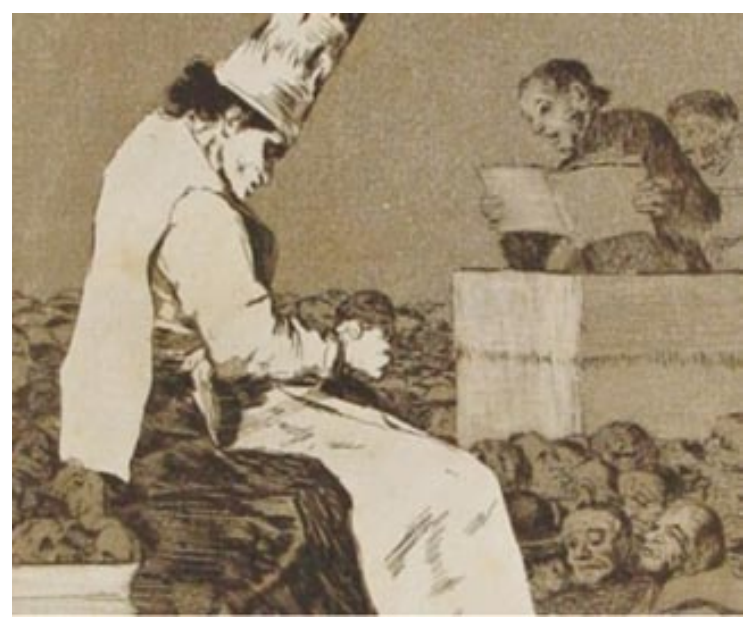

Capricho 23, Aquellos Polvos.

las supersticiones e ignorancia del pueblo se expresa en esas romerías y procesiones en que los personajes van vestidos a la moda pasada del siglo XVII (Mena, 2002, p. 58).

Caprichos es quizá la obra más explícita de crítica a la sociedad de su época, pero sus pinturas anteriores también reflejan cierto cuestio-

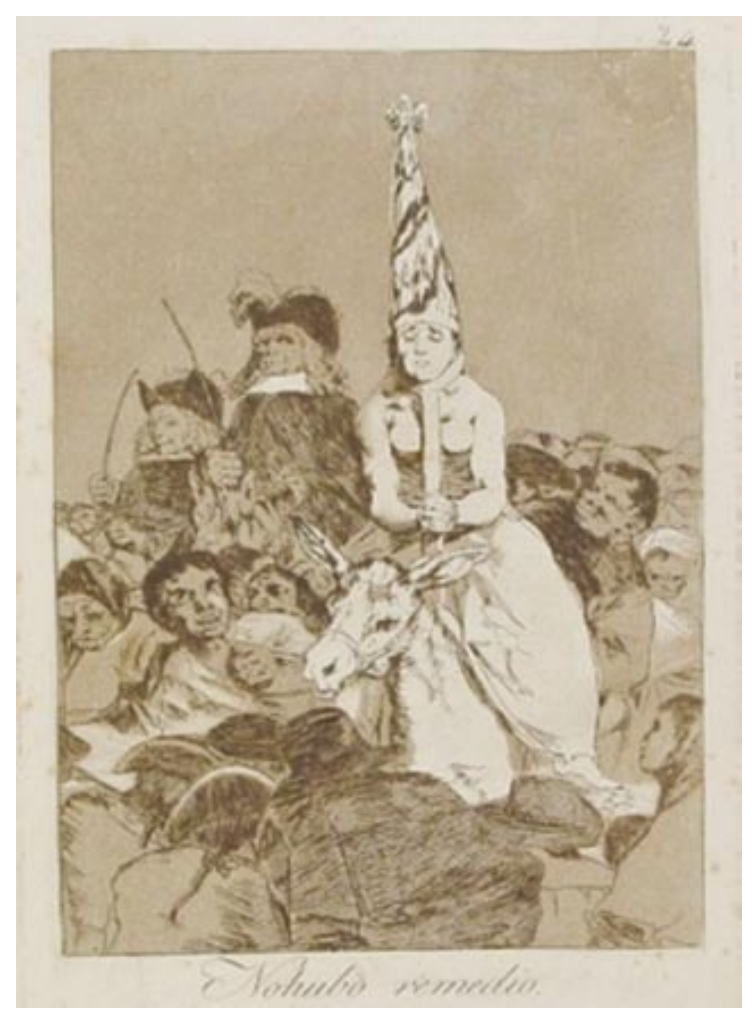

Capricho 24, No Hubo Remedio 


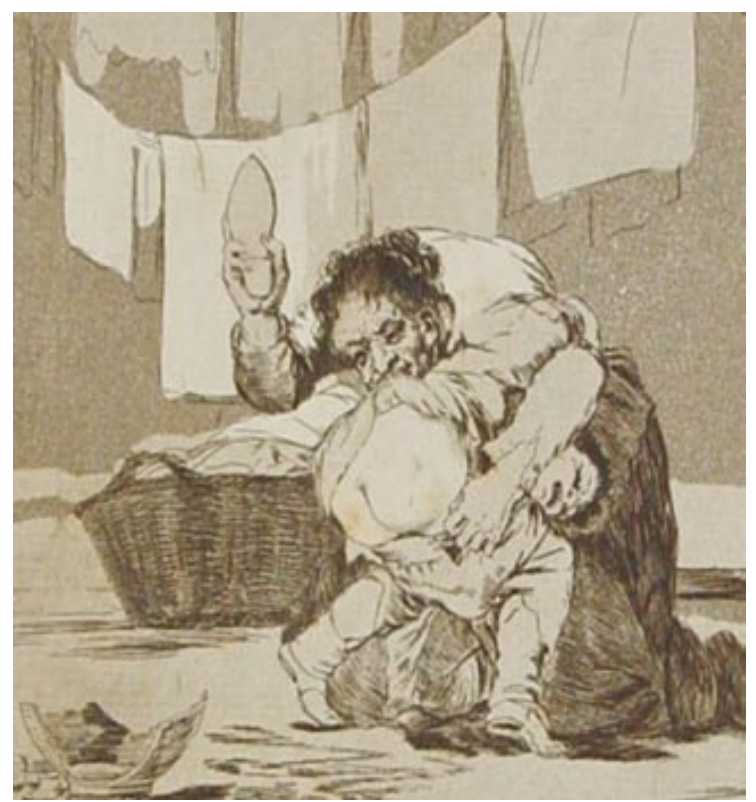

Capricho 25, Si quebró el cántaro.

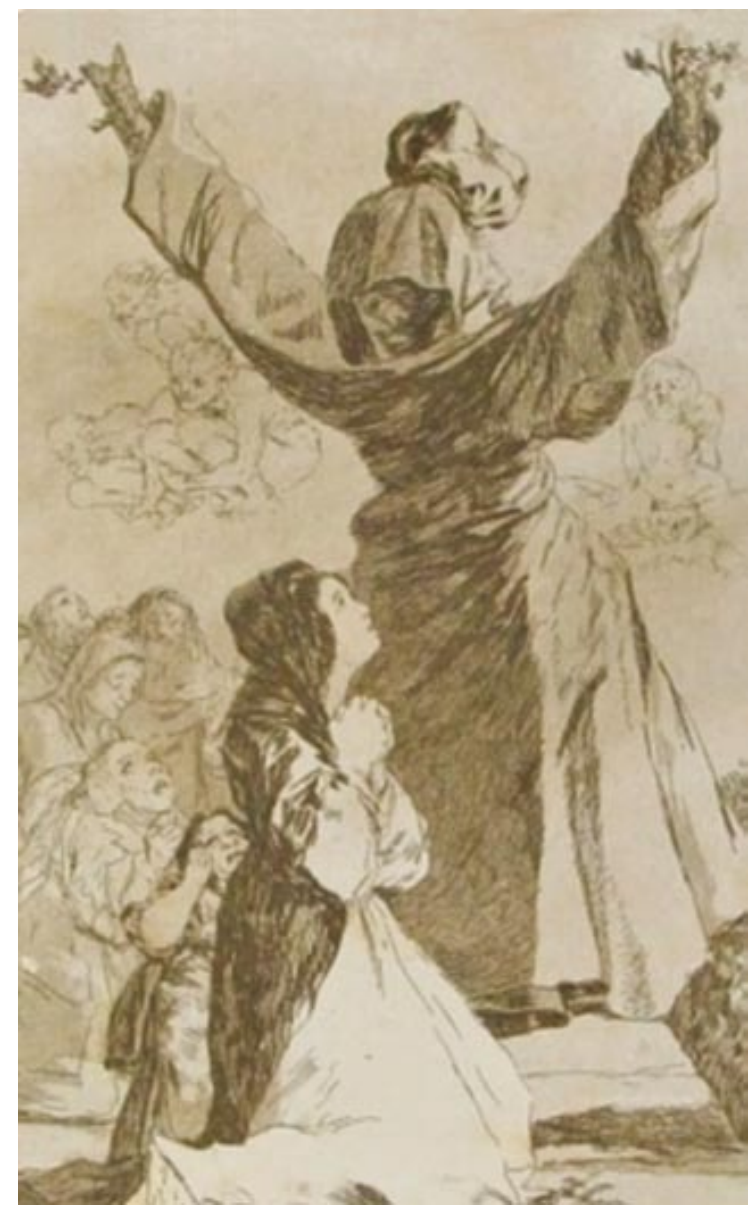

Capricho 52, Lo que puede un sastre. namientos. Por ejemplo, en los cartones para tapices, realiza una pinturas de estilo realista de las condiciones de la población humilde, como podemos observar en El albañil herido (1786-1787), La nevada (1786-1787) y La boda (1791-1792). En la primera y segunda intenta retratar las dificultades de la gente pobre, y en la segunda se burla de los matrimonios por conveniencia, donde un hombre viejo y feo se casa con una mujer joven y hermosa.

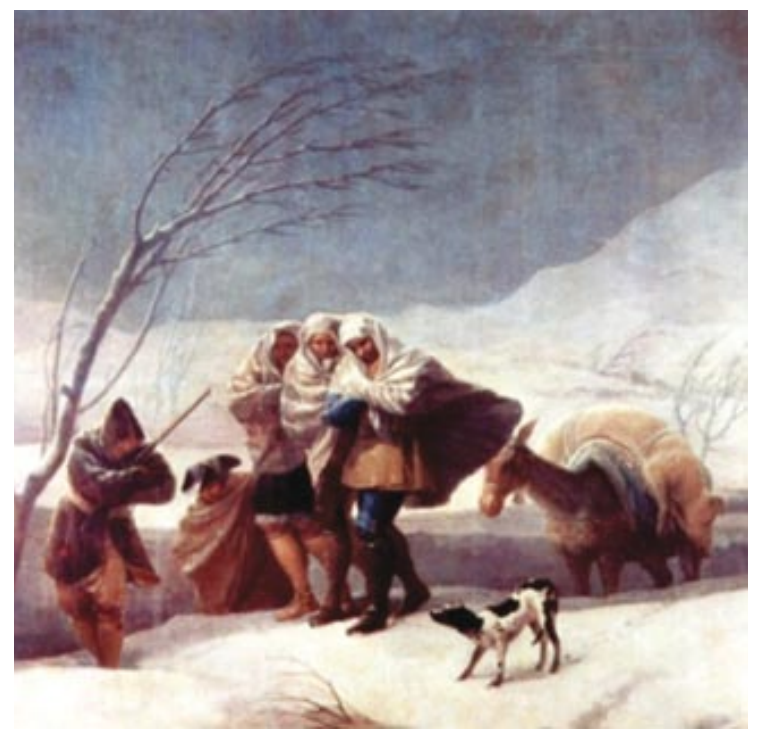

La nevada (1786-1787)

Es importante destacar que Goya pintó a las mujeres, proveyéndoles un papel particular en sus cuadros, una crítica, una revelación o un llamado de atención. Les atribuyó dos fuertes críticas: la primera referida a la femineidad como un instrumento de seducción para conseguir el compromiso de los hombres y su impiedad para con los amantes, la segunda, la codicia de las celestinas quienes siempre están detrás de las mujeres jóvenes.

Afectado por los acontecimientos del 3 de mayo de 1808, cuando las tropas francesas de Napoleón llegan a Madrid y ordenan la ejecución de una manada de campesinos, artesanos, mendigos y frailes que se encontraban en el mercado el amanecer del 2 de mayo de 1808, el pintor de Zaragoza inicia una nueva fase en su prolífica 
obra. Goya, aunque coincide con la ideología de la Revolución Francesa, rechaza vehementemente los actos de violencia cometida por los franceses al pueblo español. Por tal razón, se retira a su ciudad natal, y elabora una serie de cuadros que recrean los desastres de la violencia. En 2 de mayo de 1808: La carga de los mamelucos, un óleo sobre lienzo, encontramos una lucha entre el ejército francés y los españoles, destacándose los mamelucos, mercenarios egipcios a órdenes del ejército francés utilizando sus espadas, caballos alborotados sometidos a la confrontación, mientras los españoles empuñan sus cuchillos, con la ciudad como telón de fondo, en donde no hay vencidos ni vencedores, haciendo mención a la insensatez de la guerra, "A Goya solo le interesa reflejar cómo tratan los hombres a los hombres, cómo el caos y la lucha hacen a los ciudadanos bestias" (Rose \& Hagen, 2005, p. 56).

Otra de sus obras maestras de este periodo es Los fusilamientos del 3 de mayo, que recrea el fusilamiento de cerca de 400 hombres españoles a manos del ejército francés, en el que expone la crueldad de esta masacre. Una víctima que mira de frente la muerte y la espera con los brazos extendidos, unos soldados anónimos inmóviles sin mirar a los ojos a sus víctimas, máquina de guerra que aplasta la insurrección. Estos dos cuadros constituyen un ícono de la resistencia española.

Goya pinta una colección con la misma técnica de caprichos que recrea la guerra, la guerrilla, la violencia, la crueldad, el despojo, la miseria, las atrocidades, nunca antes vista en la historia europea. Esta colección consta de 82 grabados que bautizó: Los desastres de la guerra y constituye un verdadero manifiesto contra la violencia.

Goya destaca en la colección tres cuestiones: primero, la crueldad y las atrocidades de la guerra; segundo, la miseria y el hambre del pueblo como consecuencia de la guerra; y tercero, el totalitarismo -ni Napoleón ni Fernando VII-. Podemos exaltar las siguientes como una muestra de su crítica a la violencia: Que valor y Son unas fieras distinguen el papel de la mujer, en una situación de confrontación, donde pierde su rol para sumarse a la guerra. En la primera se refiere a Agustina de

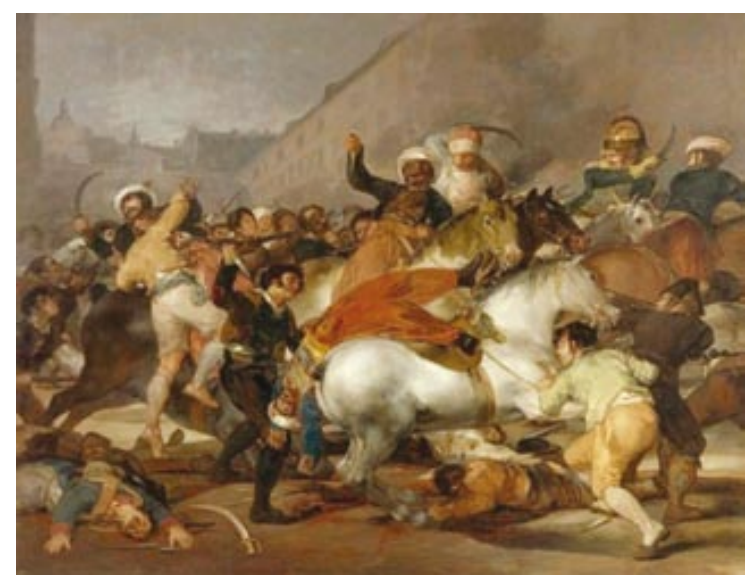

2 de Mayo de 1808 (1814).

Aragón, quien dispara un cañón después de que han muerto todos los hombres; en la segunda, una mujer empuña con una mano el arma y con la otra el brazo de su hijo.

Tampoco, en el que cuestiona el sentido de la matanza, "Jacques Callot había hecho antes que Goya grabados sobre desastres de la guerra. Su lámina de los ahorcados no deja duda respecto al sentido de la matanza, puesto que los versos acompañantes los califican de bandidos" (Rose \& Hagen, 2005, p.59), razón por la cual se intuye que Goya también intenta provocar en el observador cuestionarse por el sentido de la matanza, al realizar un grabado similar al de Callot.

Estragos de la guerra recrea el bombardeo del ejército francés a la población civil de Zaragoza, convirtiéndose en un precedente del Guernica,

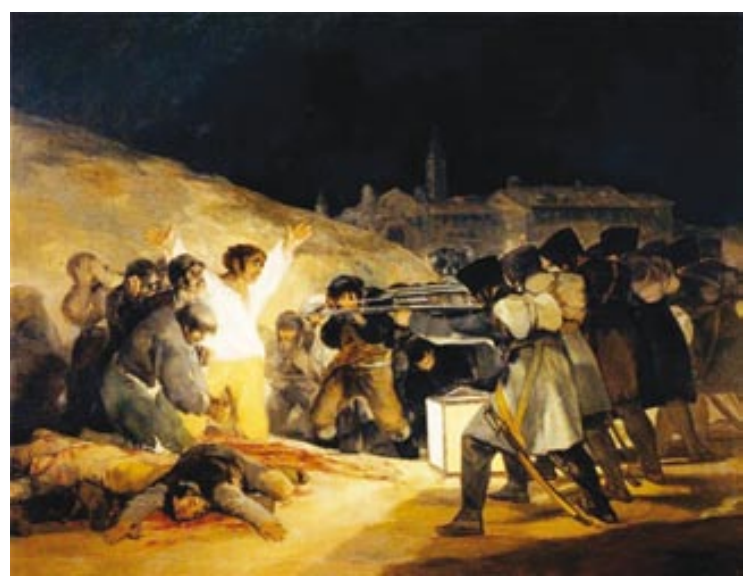

Los fusilamientos del 3 de Mayo (1814). 


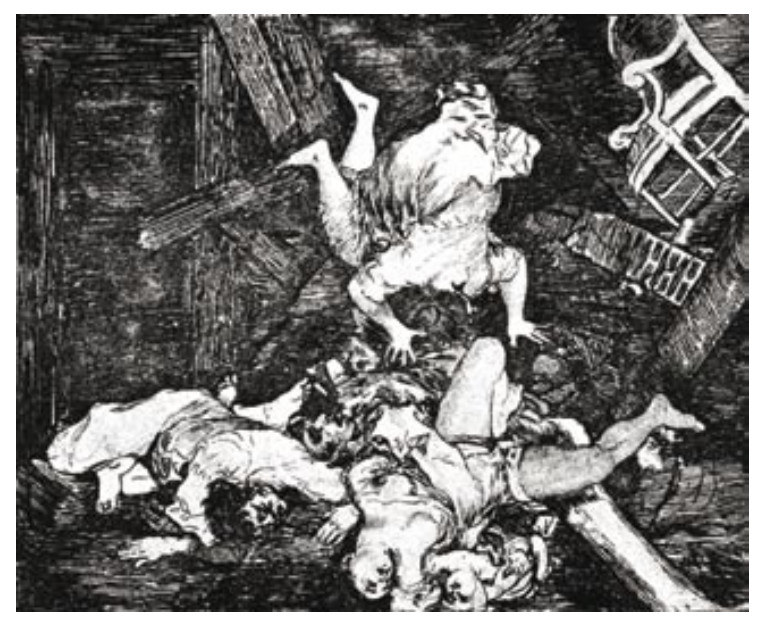

Desastres de la Guerra Nº30, (1810-1815).

reconstruyendo el caos, la crueldad y el sufrimiento de una mujer y un niño; en Esto es peor un hombre es atravesado por un árbol y "iQué bay que hacer más?" escenifica a unos soldados franceses torturando a un hombre que no se puede defender.

Carretadas al cementerio hace parte de su serie sobre la miseria y la pobreza en la guerra, mostrando la muerte por causa directa de ésta y la muerte por la hambruna que ocasiona la misma.

En la última serie de los grabados, Goya llama la atención sobre los totalitarismos, como la represión de Napoleón rompió con los ideales liberales y la restitución de Fernando VII trajo de vuelta el absolutismo. En Contra el bien general un tirano que escribe los designios, sin el con-

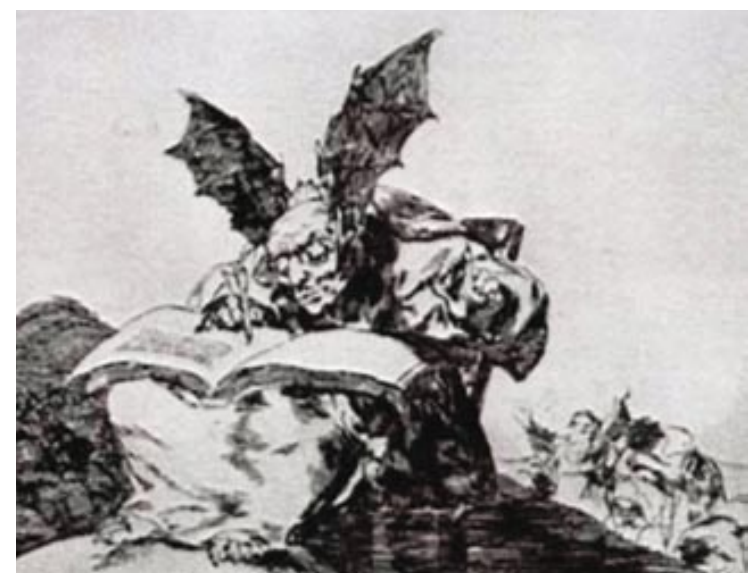

Contra el Bien General, № 71, (1810-1815). sentimiento de los ciudadanos y representado por un demonio, y Que se rompe la cuerda es una clara alusión sobre la forma como la iglesia, aunque caminando por un delgado hilo, logra pasar por encima del pueblo y restituirse junto con el reinado de Fernando VII. Más tarde, en 1812, pintaría Tribunal de la Inquisición, lo cual pudo haberle traído dificultades a Goya, por cuanto su obra fue considerada propaganda anticlerical en tiempos de Fernando VII.

De esta forma, Goya hace reflexionar sobre el discernimiento de la violencia, la cual no logró ni posicionar las ideas liberales ni mantener el statu quo, sino que ocasionó el devenir del absolutismo y los desastres de la guerra. Trajo exactamente eso: desastres. Ni progreso, ni pensamiento, ni ideas. Y todo ello podremos recordarlo en la obra de Goya.

\subsection{Pablo Picasso (1881-1973): Guernica}

Después de la obsesión de Caravaggio por la realidad y la fuerza de la verdad, Picasso plantea la posibilidad de plasmar la realidad de acuerdo a la percepción que cada quien tiene sobre el mundo, dejándole a la fotografía la tarea de captar la realidad tal y como se presenta. De esta forma, surgió la reflexión sobre ¿cómo es la realidad?, ¿Cómo vemos la realidad? ¿Por qué se le da diferentes lecturas a un mismo hecho, estando los observadores en el mismo punto? A pesar de que el arte intentó crear unas reglas generales sobre color, tono, forma y volumen para reflejar una escena real, Picasso demuestra que percibimos las cosas y las personas de una manera mucho menos hiperreal. Rompe con la belleza europea para esquilar y cuadricular sus pinturas, haciendo de la pintura una opción de múltiples sentidos, de la percepción sobre las personas, las figuras, las cosas, el mundo -el cubismo-. "Picasso decía estoy yendo más allá, me alejo de lo superficial y voy directo al corazón” (Schama, 2006).

Aunque Picasso se declaró pacifista y comunista, al igual que muchos artistas, estuvo por varios años lejos de considerar la política como 
asunto suyo. Se coloca en el peldaño de lo sublime. No obstante, lo que sucede, es lo que nos sensibiliza, precisamente lo que acontece en el mundo.

Las primeras obras famosas de Picasso hacen referencia a la pobreza (Las dos hermanas, Pobres a orillas del mar, La celestina), influenciado por la realidad de la Barcelona de principios del siglo XX, donde era frecuente la miseria y la mendicidad. Este periodo se le ha denominado la época azul de Picasso.

En el mismo año que pinta la Guernica, influenciado por Henri Toulouse Lautrec, elaboró unas tiras cómicas, haciendo una crítica satírica sobre las pretensiones de Franco, que bautizó Sueños y mentiras de Franco, mofándose del fascismo franquista y mostrando a un Franco ordinario y grotesco.

Pero sólo sería hasta la Guerra Civil Española y especialmente hasta el bombardeo sobre la ciudad de Guernica en 1937 que Picasso consideraría pintar concretamente para hacer alegoría a los desastres de la violencia. El Gobierno Republicano, particularmente una comisión liderada por el Director General de Bellas Artes, le había pedido a Picasso un mural para participar en el pabellón español de la Exposición Internacional de París. La barbarie de Guernica sería lo que inspiraría a Picasso. El periodista George Steer, del Times London, como testigo y reportero, publicó los hechos en el periódico, convirtiéndose en el primer portavoz internacional de este suceso.

La obra mezcla imágenes del dolor y la angustia de las mujeres, de esperanza y rebeldía que desaparecen ante la trágica y brutal violencia, haciéndonos entender que la violencia elimina por completo el optimismo, la esperanza y la voluntad de lucha. Mientras que Goya coloca un rebelde desafiante con las manos extendidas como la crucifixión, con la esperanza de salvación, Picasso no deja ningún hilo de esperanza. En el análisis que Schama realiza, agrega: "¿Qué puede hacer el arte cuando las bombas caen?, instruirnos en la obligación de ser hu- manos" (Schama, 2006). De esta forma, otro de los artistas más influyentes de la historia reciente llama la atención sobre la atrocidad de la guerra, sobre la irreversibilidad de las consecuencias de la violencia, sobre la anulación del ser. La obra se convirtió en símbolo de la lucha antibelicista.

Relata Simon Schama que, en febrero 2003, una delegación de EEUU ante la Organización de Naciones Unidas (ONU), encabezada por Colin Powell, Secretario de Estado de ese momento, presentan la posibilidad y justificación de una intervención armada en Iraq, ante el Consejo de Seguridad de la ONU. Cuando Powell se disponía a realizar la presentación, estaba la Guernica como tapiz de fondo, por lo que pidieron taparlo con una sábana azul, haciendo, según Schama un: "halago involuntario al poder del arte", porque pueden eliminar a los dictadores, enviar ejércitos a donde se quiera, pero no pueden anular una obra maestra, símbolo de la monstruosidad de la guerra.

Después de Guernica, Picasso confesaría que tras tantos años de opresión, no luchaba sólo por el arte en sí, sino por su propia humanidad, llamando la atención sobre la necesidad de reflexionar sobre lo que vivimos y podemos influenciar: "Lo digo con orgullo, nunca he considerado la pintura como un arte destinado a distraer o a divertir. Con el dibujo y el color como armas, he intentado profundizar el conocimiento del mundo y del ser humano, a fin de que este conocimiento nos dé a todos una libertad cada vez mayor [...] Si, considero que con mi pintura he luchado como un verdadero revolucionario" (Picasso, citado por Walther, 1999, p.10). En este sentido, es indispensable destacar dos pintura más en relación con su compromiso por el movimiento pacifista, La paloma de la paz. de 1949 y La Masacre de Corea, de 1951. Picasso pertenecía al Partido Comunista Francés, el cual le pide realizar una pintura que simbolice el Movimiento por la Paz e ilustre las reuniones que tuviese el Consejo Mundial por la Paz.

En 1951 realizó la obra Masacre en Corea,-inspirado en Goya-, donde vuelve a recrear el dolor 
de las mujeres y los niños, contra unos hombres con rostros ocultos que parecen máquinas al servicio de la violencia. Resalta la destrucción, la violencia y la agresividad, y visibiliza las expresiones de miedo, terror y deseos de huir, al tiempo que muestra el aberrante uso de la tecnología para la guerra.

\subsection{Diego Rivera (1886-1957): Las paredes hablan de política}

Disponer de las paredes de una ciudad al servicio de la expresión. Cambiar las bellas musas por los ciudadanos cotidianos quienes pueden verse retratados mientras caminan por las calles, por el espacio público. Recordar la historia cuando se va de la casa al mercado y viceversa. Protestar en pleno centro financiero de Nueva York, sin que haya una sola agresión: únicamente una pincelada crítica justo en el centro del corazón de un sistema económico en cuestión.

"Rivera elabora para sí un concepto de arte al servicio del pueblo que deberá conocer su propia historia a través de la pintura mural" (Kettenmann, 2006, p. 23), lo que no sólo constituye un giro inesperado y creativo en el arte, sino una contribución política a la historia mexicana y latinoamericana. Pero para ello tuvo que desobedecer los parámetros artísticos, los ideales de belleza europea para destacar la belleza indígena, mestiza y campesina. Dejar de retratar a quienes se ubican en la cúspide de la pirámide social para retratar al pueblo llano. Rivera se interesó por combinar arte y política, luego llegaría la influencia de las ideas comunistas y el rescate por la identidad nacional autóctona.

En 1924 el pintor termina los murales de la Secretaria de Educación Pública (SEP). Son 1600 metros cuadrados en el que el artista retrata tres aspectos: el primero, los ideales revolucionarios que celebran la herencia cultural indígena de México; el segundo, escenas de la vida cotidiana de la gente del común realizando quehaceres agrícolas, industriales y artesanales; el tercero, las fiestas populares mexicanas.
Rivera destaca el trabajo extenuante de la clase popular con la representación de los mineros, el trapiche y la agricultura. El papel de la mujer, Mujeres Tebuanas y la Maestra Rural, este último con el objetivo de homenajear la valiosa labor de profesor. El artista explicó que sobre el patio de fiestas quiso señalar las fiestas que representaban la idiosincrasia del pueblo mexicano: desde las simbólicas hasta las cotidianas. Desde la fiesta del maíz, pasando por la fiesta del día de los muertos, hasta los matrimonios, llegando por último a las canciones o coplas alusivas a la revolución agraria y la revolución proletaria. Afirmó que: "figuras alegóricas representaban los estadios ascendentes de la evolución social del país a través de las revoluciones populares, desde una sociedad primitiva hasta el liberado y pleno orden social del futuro -Marzo de 1963" (Rivera, 2007).

Luego, Rivera realizaría los murales del Palacio Cortés en Cuernavaca, donde destacó la colonización y sus devastadores consecuencias. En los murales para la Escuela Nacional de Agricultura señaló la imperiosa necesidad de la distribución de las tierras, y después, en los muros del Palacio Nacional de la ciudad de México se dedicó a elaborar una muestra narrativa de la historia mexicana desde los Aztecas hasta el siglo XX.

La fama de los murales de Rivera, junto con los de José Clemente Orozco y David Alfaro Siqueiros, quienes hicieron del muralismo una fuerza artística novedosa, permitió que John Rockefeller Jr. le propusiera a Rivera pintar el mural del lobby del edificio Rockefeller Center. El mural contenía la obra El hombre en el cruce de caminos o El hombre controlador del universo, una clara alusión al hombre capitalista que se encuentra en la controversia del individualismo a merced de sus intereses y el deseo del hombre por controlar el universo. Crítica al capitalismo en pleno corazón de Nueva York. El retrato de Lenin, no aprobado en los bocetos, provocó la decisión de destruir el muro. Luego Rivera lo volvería a pintar en México.

Antes de los sucesos del Rockefeller Center, Diego Rivera había trabajado en San Francisco, 
donde realiza Alegoría de California para el Luncheon Club y unos frescos titulados Detroit Industry, para el Instituto de Artes de Detroit. En éste predomina la rutina de trabajo en la fábrica, las instalaciones industriales, la inmortalización de la cadena de montaje del Ford V8, las tecnologías aéreas y marinas, el triunfo del hombre sobre la naturaleza y, por supuesto, los abusos de la industria en Detroit, representada por la mano empuñanda de trabajadores que reclaman bienestar. A finales de 1930 el artista realizó una exposición de 130 obras de su autoría en el Palacio de la Legión de Honor en California.

Rivera no sólo retrata la historia, los fenómenos sociales y políticos de su época, sino que nos enseña que el arte tiene un papel humanístico y político en el desarrollo de las sociedades y que el artista debe ser un ciudadano responsable y comprometido con lo que nos es común a todos: el vivir juntos. Su última obra, Desfile del $1^{\circ}$ de mayo en Moscú, de 1956, retrata un globo con las palabras paz y libertad, lo que denota una transición en la ideología política de Rivera, primero la protesta y la reivindicación del pueblo, luego el clamor por hacer realidad la paz y la libertad.

\subsection{Marc Chagall (1887-1985): El respeto por el otro}

Un buen ser humano puede ser, como es sabido, un mal artista.

Pero quien no sea un gran hombre y por ello un buen hombre, no será nunca un verdadero artista

M. Chagall

La obra de Chagall es quizá la más difícil de relacionar directamente con arte desobediente. Es posible exponer un argumento muy fino entre la obra de Chagall y un llamado a la tolerancia y al respeto por el otro, tan importante en el argumento sobre la consciencia y cálculo moral de nuestros actos con respecto a lo público, base fundamental para tomar la decisión consciente de obedecer o desobedecer.
Deseo destacar, tanto en la vida y obra de Chagall, la permanente evocación de ser un ciudadano del mundo. Sus pinturas en París eran extrañas. Estaba acompasado por los movimientos de principios de siglo, el fovismo y el cubismo, pero recreando los paisajes y la cotidianidad propia de la desconocida ciudad de Vistebsk en Europa del Este, hoy en día en Bielorrusia.

Aunque vivió en París, tuvo que regresar a su ciudad natal donde no puede escapar de la Revolución Rusa y es reclutado para prestar el servicio militar, tiempo durante el cual no pudo trabajar en sus cuadros y debía sellar papeles en una oficina en San Petersburgo. Una vez instalado el gobierno de Lenin, lo nombran Comisario de Bellas Artes en su ciudad natal, donde se dedicó a organizar exposiciones, inaugurar museos e imprimirle vida a la enseñanza en la academia de Bellas Artes. Su obra no satisfacía los requerimientos del nuevo gobierno que deseaba pinturas que hicieran homenaje y halago a la revolución, por lo cual es destituido de su cargo en 1920 y regresa a Moscú, donde vive en extrema pobreza, pues el gobierno sólo apoya a los artistas en virtud de su contribución política. Emigra a Berlín para recuperar unos cuadros y luego vuelve a París. Con la latente persecución a los judíos, decide aislarse en el sur de Francia, pero es capturado en Marsella, logrando luego escapar con ayuda estadounidense antes de ser entregado a los nazis. En 1941, Chagall llega a Nueva York.

Durante este periodo se destacan tres de sus obras: La revolución, de 1937, una expresión de la desazón sobre la política, recreando dos visiones diferentes, la de los revolucionarios victoriosos y la de los personajes que sueñan con la igualdad y la libertad, danzando alborotadamente. Precisamente, al respecto Chagall comentó: "Pienso que la revolución podría ser una gran cosa, si mantuviera el respeto por lo que es diferente" (citado por Ingo \& Merzger, 2007, p. 48). Esta pintura se expuso junto con Guernica en la Exposición de París.

Crucifixión blanca, de 1938, es la obra donde Chagall explícitamente manifiesta su voz de 
protesta por los acontecimientos de la revolucionada Europa. Describiendo: "las desgracias de su propio tiempo" (Ingo \& Merzger, 2007, p. 62), reúne varias escenas de confusión: un judío huyendo delante de una Tora en llamas, revolucionarios con banderas rojas que asaltan la aldea, la profanación de una sinagoga por un nazi, personas horrorizadas, fugitivos que piden ayuda en un barco, unos sacerdotes aterrados que se tapan los ojos.

La Impugnación, de 1943, la pinta en su condición de exiliado en Estados Unidos, dominado por los temas bélicos y las atrocidades de la guerra en Europa. Expone nuevamente el miedo, la huida, la caída del Cristo crucificado, el judío horrorizado.

Chagall combinó muchos elementos que resaltaban la integración. De tradición judía, vinculó elementos cristianos, combinó la vida del campo con los símbolos de la metrópoli, homenajeó el amor de los amantes, se manifestó en contra de la guerra y sus consecuencias. Como Walter Ingo y Rainer Metzger señalan: "su fuerza de integración satisfizo el anhelo del público de una humanidad unida como una familia armónica, de un mundo en paz fraterna" (2007, p. 89), y precisamente ese llamado a la tolerancia, al respeto por el otro y al rescate de la humanidad del horror de la violencia contribuye a la concientización de los seres humanos por nuestra responsabilidad como ciudadanos del mundo, promueve el pensamiento, la reflexión y coherencia entre la conciencia moral y los actos, lo cual aporta a identificar las razones de la desobediencia civil.

\subsection{George Grosz (1893-1959): Denunciar lo absurdo}

Grosz utilizó su pintura decididamente para denunciar las barbaries de su época, atacando el tema nazi, el militarismo y sus simpatizantes, y el consumismo: "combinar política radical con arte radical, para criticar la injusticia" (Schama, 2006) afirmaba. Impresionado por la Revolución Rusa, elabora la obra Ecce Homo, una fuerte crítica al periodo entre guerras y al absurdo de la violencia. Inscrito en la corriente dadaísta de los años veinte y luego en el movimiento de la nueva objetividad.

Participó en el Salón Dadá de Berlín, en 1920, donde su obra es una clara muestra de la postura antimilitarista. Alemania, un cuento de invierno (1917) es una crítica al poder, que representa con el militar en el centro, el clérigo a un costado y el político capitalista al otro costado, mientras que la clase media vive en un caos.

La Ciudad (1916-1917) señala una metrópoli convulsionada, caótica, donde no se puede distinguir absolutamente nada, al igual que Explosión (1917), que refleja el desastre, el caos y lo absurdo de la destrucción. En El Blanco Negrero (1918) se ve a un agiotista, cuidadoso, paranoico, cuyo telón de fondo es confuso, oscuro y tenebroso. En República de autómatas (1920) muestra a los humanos convertidos en máquinas, en cuyas cabezas vacían slogans. La ciudad son bloques rigurosamente colocados, visibilizándose una ciudad deshumanizada y el deseo de regular y ordenar una ciudadanía autómata.

Día gris, de 1921, es una obra pesimista, colocando al clérigo poderoso en primer plano; un veterano militar, agobiado, demente y deshuma-

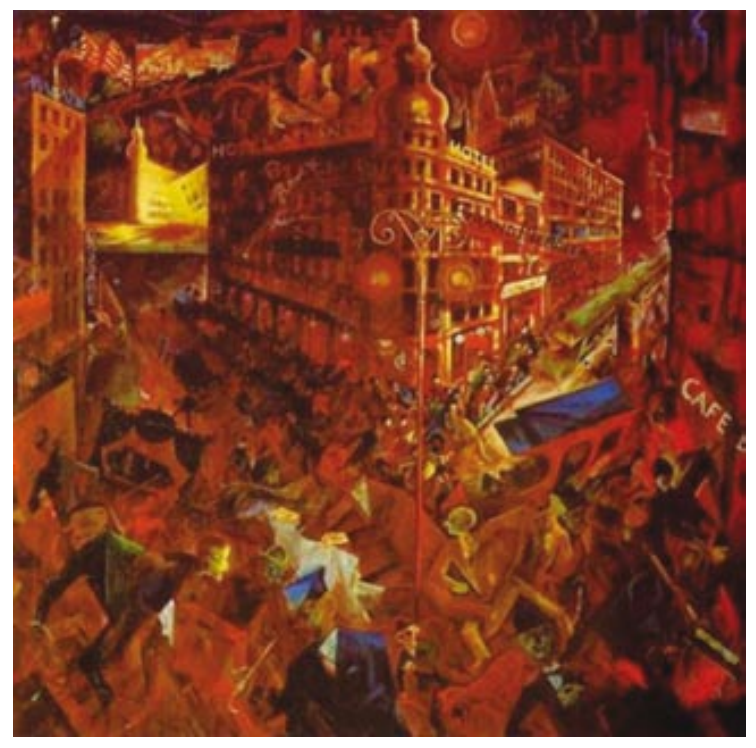

La ciudad (1916-1917) 


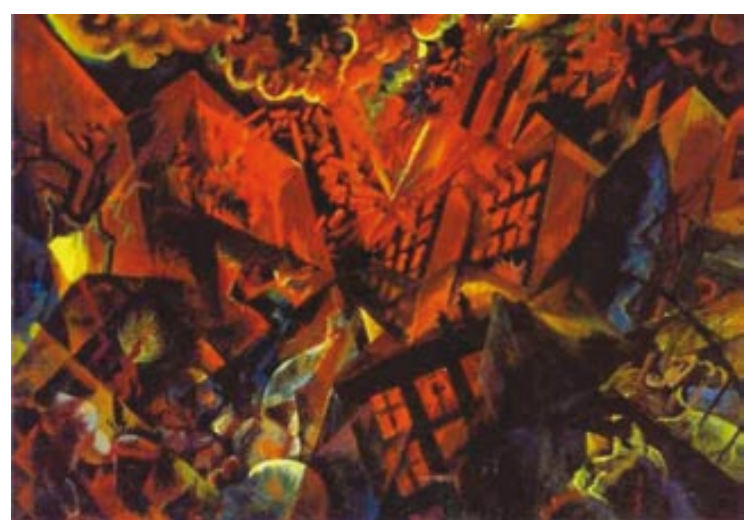

La Explosión (1917).

nizado; al burócrata escondido detrás de la pared $\mathrm{y}$ al obrero sin rostro y sin esperanza. Mientras que en Los pilares de la sociedad (1926) muestra de manera directa a un dictador que no tiene nada en la cabeza -una concordancia con Hannah Arendt quien describiría la banalidad del mal y el autoritarismo como la ausencia de pensamiento-. Este personaje empuña una espada con vehemencia. Justo atrás se encuentra el industrial que tiene mierda en la cabeza y el periodista al costado izquierdo con un casco que simula el casco militar, pero es una taza, con el periódico

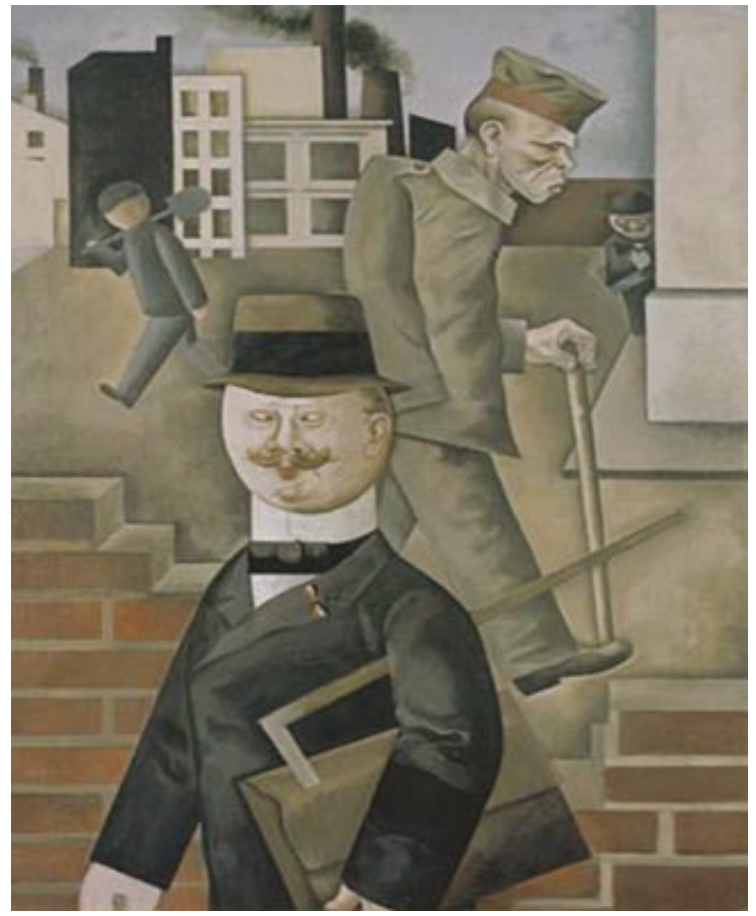

Día Gris (1921) entre sus manos, en una clara crítica al periodismo que fomenta la opinión pública y que está cerca del tirano como un bufón.

Eclipse de sol (1926) muestra los políticos sin cabeza, un burro que se come las leyes, el sol está contaminado por el dinero, el militar controla al capitalista, la espada está untada de sangre y amarrada a una cruz, como si la iglesia cohonestara con el autoritarismo. El agitador, (1928), es una burla a los líderes del momento. En una mano, el personaje central tiene la trompeta con la que vocifera y en la otra, el hacha con la que reprime. Los espectadores están absortos y la ciudad está en caos. Interrogatorio Nazi (1936) y Cain o en el infierno de Hitler (1944) crítica abiertamente el régimen nazi. En el primero, el artista representa un típico sometimiento de un capturado por el régimen nazi y en el segundo, una escenificación del infierno con un personaje que puede ser un militar nazi o Hitler, sentado y cansado de las llamas del infierno, otra alegoría a lo absurdo de la guerra.

Una vez que Hitler se posesiona en el gobierno alemán, Grosz huye a Estados Unidos, donde recibe el asilo y posteriormente la ciudadanía.

\subsection{Mark Rothko (1903-1970): El arte por encima del dinero}

Rothko decía que: "un sentido de lo trágico estaba siempre con el cuándo pintaba" (Schama, 2006). Como una premonición a la realidad de la Segunda Guerra Mundial, Rothko deja ver la tragedia de la brutalidad del hombre sobre el lienzo, la escenificación de la muerte, el sacrificio y el destripamiento.

En 1958 a Rothko se le encarga una serie de cuadros que deben decorar el restaurante Las cuatro estaciones, del recién construido edificio Seagram, sede de la Corporación Seagram, destiladora de licores. Mies Van Der Rohe fue el arquitecto que diseñó el moderno edificio, símbolo de modernidad y del mundo industrial. Rothko acepta el encargo y utiliza colores que van del 
rojo al oscuro marrón. La utilización de colores es la característica principal de la tendencia del artista y de colores oscuros, particularmente en dicha época. Elabora cerca de 40 pinturas para el edificio Seagram.

Después de un viaje que realiza por Europa, decide cenar junto con su esposa en el restaurante Las cuatro estaciones, pero su experiencia allí le hace tomar la irreversible decisión de cancelar el contrato, afirmando que: "nadie que coma y pague tanto dinero por una comida, podrá ver mis pinturas" (Schama, 2006), rechazando un trabajo de dos y medio millones de dólares.

Antes de rechazar el encargo, el autor había reflexionado sobre la obra que debía llevar al edificio Seagram, definiendo que sus pinturas deberían causar estupor en quienes acudieran al restaurante a cenar. Deseaba que los cuadros dañaran el almuerzo, que las personas se sintiesen cuestionadas: ¿cómo podrían cenar tranquilamente, mientras el resto del mundo se confronta armadamente? Rothko quería que los observadores de sus obras pudiesen cuestionar la América consumista, mientras que el resto del mundo sufría los avatares de la guerra, en el marco de la denominada Guerra fría. Había afirmado que después de la Segunda Guerra Mundial, el Holocausto y las guerras que persistían alrededor del mundo, no podría volver a pintar cuerpos que no estuviesen mutilados. Rothko se ofreció a pintar de manera gratuita para una capilla o espacio que hiciese expiación al Holocausto, pero nunca recibió una propuesta con tal fin.

Cuando se le cuestionaba a Rothko por su particular forma de pintura y se le calificaba como arte abstracto, solía responder que su objetivo e interés principal era provocar en el espectador de sus obras emociones y experiencias interiores, que pudiese ser una invitación a la reflexión y a la retrospección de cada individuo. Temía que dijeran que sus pinturas eran hermosas, por el contrario, deseaba causar emociones fuertes, tragedia, placer, drama. "El deseo era tener poder, el poder de llevar a la gente donde pudiera recobrar la humanidad" (Schama, 2006).
El último trabajo de Rothko fue la elaboración de una obra de gran formato para la capilla de la Universidad Católica de Houston, encargo que aceptó con la condición de que pudiese desarrollar sus propias ideas. El objetivo era lograr un espacio para la meditación y la reflexión. Trabajó sobre unos cuadros monocromáticos oscuros de gran tamaño, cuyo objetivo del autor era motivar la trascendentalidad, la cavilación y la introspección, sensaciones que deseaba provocar en sus últimas obras.

\subsection{Frida Kahlo (1907-1954): Rebelde}

Frida Kahlo encierra en su vida y obra un sinnúmero de simbolismos que rompen diferentes estereotipos tanto en el arte como en la vida cotidiana. Lleva su vida privada a la pública a través del arte y su vida está mezclada entre su amor por el muralista Diego Rivera, su vínculo con la izquierda, el nacionalismo mexicano y una serie de actos tanto artísticos como personales que rompen no sólo con el tradicional rol de la mujer, sino con la misma concepción pictórica.

Nació en Coyoacán-México, el 6 de julio de 1907. A los seis años de edad contrajo poliomielitis, lo cual marcaría su vida, desencadenando una serie de dificultades en su salud. El accidente en un autobús, en 1925, marca una fisura significativa tanto en la vida como en la obra de la artista. En medio de su intensa recuperación y prolongada convalecencia, pinta autorretratos, que luego conducirá hacia expresiones más íntimas y perceptivas de su sufrimiento físico y su ansiedad por la vida, reflejadas en imágenes complejas que representan más el mundo de las ideas y la percepción de la artista, lo cual mereció que el mismo André Bretón, pionero y firmante del manifiesto surrealista, reconociera que la obra de Kahlo se inscribía en esta corriente.

Luego de su lenta recuperación se inserta nuevamente a una vida más activa, tiempo durante el cual conoció a Diego Rivera, quien constituye la segunda gran fisura de su vida. Su pro- 
funda admiración por el muralista y su vida en pareja desarrollaron en la obra de Kahlo mayores simbologías en torno al amor y la política. Diego Rivera reflejaba en sus murales su tendencia marxista, al tiempo que destacaba la mexicaneidad y las luchas sociales alrededor del nacionalismo (ver supra), ideas que Frida Kahlo compartía y acompañaba con su activismo político, el manejo del color en sus pinturas y su vestuario ${ }^{4}$.

El contexto en el que se desenvuelve la vida y obra de la artista es el de principios del siglo $\mathrm{XX}$, cuando la lucha feminista apenas comenzaba a hacerse visible. Por otra parte, es necesario insistir en la importancia del contexto local. México vivía años revolucionarios al inicio de siglo, luego de la dictadura de Porfirio Díaz. La revolución mexicana se convertía en el mayor orgullo de nacionalidad, el rescate por lo autóctono, la reivindicación de lo local, de la historia y de la cultura propia. Las ideas socialistas que venían del Este de Europa llegaban con mucha fuerza a una izquierda organizada en partido y quienes promulgaban una sociedad con mayor justicia social e igualdad. A esos sentimientos políticos se sumaba el hecho de la pérdida de territorio en el norte, a manos de Estados Unidos en el siglo inmediatamente anterior, hecho que permanecía con fuerza en las mentes de los nacionalistas.

Las tradiciones culturales, producto del mestizaje, le otorgaban al hombre un papel protagónico, por lo tanto, era una sociedad evidentemente patriarcal. Además, la gran influencia católica hacía más fuerte esta definición de roles, de manera tal que la mujer cumplía un rol exclusivamente reproductor, así como núcleo de la estabilidad del hogar. De forma especial, la masculinidad ejercía una influencia vertical en las costumbres. No sólo se limitaba a la sociedad patriarcal sino que, con ahínco, se resaltaban en las costumbres la virilidad y la fuerza.
Las peleas callejeras, las cantinas y el licor; la visualización de la mujer como una propiedad de dignidad y reconocimiento; la promiscuidad y la virilidad manifestada en la sexualidad y la propiedad, son un conjunto del reflejo de los imaginarios masculinos. Por lo tanto, Frida Kahlo intentó golpear con la misma fuerza viril la reivindicación de la mujer militante en todos los espacios de la vida: su forma de tomar licor, de participar en las cantinas, donde la entrada a las mujeres era prohibida, la reivindicación sexual, entre otras, hacen parte de una lógica consecuencial a las circunstancias de su época.

Kahlo recreaba la lucha por la igualdad entre mujeres y hombres en el espacio cultural, en el de los imaginarios colectivos, intentando romper con esquemas de comportamiento tradicionales masculinos. En una de las fotografías familiares aparece vestida con traje entero masculino y una de sus pinturas, Cortándome el pelo con unas tijeritas, de 1940, es un autorretrato de apariencia masculina. En las reuniones sociales Kahlo bebía alcohol tanto como los hombres del lugar lo hicieran y en ocasiones más, en una demostración de igualdad y fortaleza ${ }^{5}$. Tomaba los retos de los juegos que se armaban en medio de las fiestas, besaba a las mujeres, fumaba tabaco y cigarrillo, y apostaba en juegos de azar.

Frida tuvo varios amantes, planteando quizás un juego de poder, cuestionando el rol de género y promoviendo la igualdad sexual. Si era aceptada la infidelidad masculina, si las mujeres toleraban la infidelidad de su pareja, entonces Frida proponía una reflexión desde la igualdad radical, es decir, imitar las acciones de los hombres que implicaban simbólicamente el sentido más masculino de su ser, con la intención de suscitar cuestionamientos.

La artista nos lleva a reflexionar sobre la representación de la mujer en la pintura. Aunque

4 El manejo del color en las obras de Frida Kahlo es producto del intento de reivindicación nacionalista, al igual que Diego Rivera, era frecuente el uso de colores vivos y combinaciones fuertes, verdes, rojos y naranjas.

5 Esta fortaleza debe interpretarse de dos formas: la fortaleza relacionada con la virilidad masculina, pero también la fortaleza que demostraba por superar sus deficiencias de salud. 
influenciada artísticamente por su esposo, Kahlo va mucho más allá: Rivera se preocupó porque los murales ilustraran las luchas sociales-indigenistas, donde la gran protagonista es la masa, aquella que trabaja y que desea romper las cadenas, la que aspira a tomarse el poder en virtud de una sociedad justa, pero:

entre la concepción de la historia que plasma en sus murales y su concepción de la mujer hay un paralelismo sorprendente [...] las mujeres no sólo están ausentes de la historia sino también de la historiografía, Diego Rivera nos sirve de ejemplo para esto último: las mujeres son los apéndices (acompañantes) de los hombres y desempeñan la dicotomía clásica de putas o santas (Bartra, 1994, p. 90).

Rivera homenajea a la mujer trabajadora, la luchadora, pero nunca llega a cuestionar el rol de género, ni en sus pinturas ni en su vida.

Pese a la dualidad de la Frida que cuestiona el género y la Frida leal a Diego, la artista logra suscitar en el espectador la reflexión sobre igualdad y justicia, en un ámbito privado que traspasa al público, como lo es efectivamente el papel de la mujer en la sociedad y en la familia. Ahora bien, la artista reconoce varios imaginarios con respecto a la naturaleza -esencia de la humanidad-, destacando elementos como la tierra y su vinculo reproductivo asociado al papel de la mujer; los dioses el sol y la luna, como los conservadores y guardianes del planeta; la reproducción como parte de la naturaleza y el vínculo estrecho entre la imagen de la mujer y su relación indisoluble con la madre tierra. Esto es evidente en El abrazo de amor del universo, la tierra, Diego, yo y el señor xolotl, de 1949. Este tipo de pinturas incluyen dos cuestiones novedosas y reflexivas: la influencia por su herencia indígena y una representación donde no predetermina roles de género. No obstante, la obra de Kahlo está llena de elementos que expresan el dolor y la tragedia, propias de una mujer como la frustración de la maternidad, la infidelidad y la vulnerabilidad.

La aparente contradicción de la artista entre la tradición indígena y la crítica a la sociedad de su época está influenciada por la mitología; así por ejemplo, la necesidad del otro (Diego) la recrea en el mito de Aristófanes:

El sol producía lo masculino y la tierra lo femenino, la luna engendraba el tercero, participando de tierra y sol. Estos últimos seres, esféricos y dobles, concibieron la idea de combatir con los dioses, y Zeus para castigarlos los separó en dos mitades; ellos, antes plenos de sí mismos, vivieron luego en un ardiente deseo de unidad, buscando ansiosamente la otra mitad, de la que habían sido separados. Su deseo más profundo era -estar unido y confundido con el Objeto Amado, hasta no formar más que un solo ser con él- (Platón, 1970, p. 117).

El amor es encarnado generalmente por la figura de una mujer, es una entidad suprema como Afrodita. Así, la artista no desvincula amor y mujer en esa relación de género que ella misma cuestiona: "El amor llena el abismo entre las acciones bajas y la bondad suprema que subyacen a cada ser. Para abarcar este espacio él asume entonces en el discurso platónico la palabra de una mujer: Diotina de Mantinea" (Thomas, 1994, p. 36). Su figura de mujer sublimiza la banalidad de Diego con un amor intenso y profundo.

Recordemos que el amor, como construcción mítica, justifica la contradicción de la artista: "Eros es el amor y es el patriarca; es la libido masculina; es inmortal y es dios. Psique es la enamorada, pero también la mujer que sólo será redimida por el amor luego de mucho sufrimiento" (Thomas, 1994, p. 34). En la mitología, Eros simboliza el amor y psique el alma que aspira a conocer este amor más allá de la palabra. Es decir, Frida se encuentra en medio de la dualidad emancipación-tradición que deja el sabor de una artista contradictoria, cuyo papel como mujer no es claro. "Frida representaba a Rivera como el gran artista que blande su paleta y pinceles; ella misma juega el papel que más le agradaba: el de la esposa amorosa del genio" (Thomas, 1994, p. 164). Esa dualidad de la Frida rebelde y la Frida sumisa pareciera no concretarse en una exposición contundente de crítica y reflexión sobre la igualdad y la justicia. 
No obstante, la vida y obra de Frida nos lleva a reflexionar, no sólo sobre la construcción de los géneros, sino también sobre cuestiones propiamente humanas: el dolor y el amor, que traspasa el escenario de lo privado y se instala en lo público, y que políticamente se traduce en el reconocimiento: aceptar el otro, la tolerancia, consentir la diferencia.

Como es natural, tratándose de dos caracteres tan fuertes motivados ambos completamente desde adentro por impulsos voluntariosos e intensa sensibilidad, su vida conjunta era tormentosa. Ella subordinó su voluntad a la de él: de otro modo hubiera sido imposible vivir con Diego [...] A pesar de las peleas, la brutalidad, las acciones rencorosas, aún en el divorcio, en la profundidad de sus seres seguían cediendo el primer lugar el uno al otro. Más bien, para él, ella venía después de su pintura y de su dramatización de la vida como una serie de leyendas, pero para ella, él ocupaba el primer lugar, aun ante su propio arte. Sostenía que a las grandes dotes de Rivera debía corresponder con mucha indulgencia. En todo caso, me dijo una vez, con una risa pesarosa, que así era y por eso lo amaba 'No puedo quererlo por lo que no es' [...] De la fusión, estructura dual, pasamos a la conjunción, estructura de terceridad (edípica); relación que aprendió a asumir la carencia porque los dos YO se saben y se admiten diferentes. Admiten la preferencia parcial, y el objeto amorosa de cada uno pasó de ser objeto único a objeto privilegiado. Hay lugar para lo otro, existen espacios para respirar, y en consecuencia es una relación que se enriquece y se alimenta del exterior. El crecimiento es mutuo y generalmente paralelo. Del 'yo soy tú y tu eres yo’ del enamoramiento, pasamos al 'yo soy yo, tú eres tú', pero nos amamos en el reconocimiento de esta diferencia (Herrera, 1983, p. 145).

De forma tal que el trío "amor, política y feminismo" se convierte en un panóptico complejo, entrelazado, lleno de imaginarios y símbolos que refleja la artista en una composición cargada de colores, fuertes elementos, autorretratos, simbologías, ensoñaciones, demostrando la indisolubilidad entre lo público y lo privado, la vida cotidiana desde su rol de género llevada a la expresión pública en el arte.

\section{Conclusiones}

$\mathrm{El}$ arte que se materializa en las obras tiene un sentido, así como las ideas políticas. Sus significados han implicado ruptura de épocas y cambio de variedad de mentalidades, convirtiéndose en un instrumento potencial para desobedecer civilmente. Es una de las formas de expresión que invita, entre otras cosas, a pensar y reflexionar, que denuncia las atrocidades de la violencia, el autoritarismo, la pobreza, la marginalidad y la inconsciencia. Se convierte en un instrumento de la noviolencia que cuestiona las reglas, influencia las transformaciones políticas, aporta en la evolución democrática, moviliza la relación moral del individuo con lo público y genera cambios deseables en materia de justicia, inclusión, otredad, libertad. Arte y política se encuentran para suscitar debates éticos y transformaciones gratas. El artículo se limita a reseñar algunas obras de pintura para visibilizar el rol del arte en la desobediencia civil y en la transformación política, resalta la relación entre las pinturas y sus autores.

Caravaggio, por ejemplo, expresa de manera visceral la cruda perversión y morbosidad alrededor de la carne, el miedo, el ostracismo y la violencia, como una cuestión infinitamente humana e infinitamente reprochable.

Además de recrear en sus obras las condiciones humildes de la población de su época, Goya critica vehementemente la violencia, mostrando a través de sus pinturas que la violencia no logró absolutamente nada, la violencia con la que pretendía la Revolución Francesa imponer las ideas liberales sucumbió ante lo que inevitablemente trae la violencia: el desastre de la muerte, el sometimiento y la miseria, e incluso condujo a instaurar nuevamente el absolutismo.

En la misma línea, Picasso denuncia a través de la Guernica cómo la esperanza, el optimismo, la voluntad de lucha y la rebeldía desaparecen ante la trágica y brutal violencia; declaró que la opresión se debía combatir y él lo hizo a través de la pintura. No sólo la Guernica se hizo célebre, la paloma de la paz que ha simbolizado la esperanza también fue obra de Picasso. Una in- 
vitación a protestar a través del arte. Grosz, por su parte, años más tarde, denunció la barbarie de la violencia de su época, atacó el tema nazi, el militarismo, el consumismo, afirmó que ante la radicalidad de la política, el arte debe criticar radicalmente la injusticia.

Rivera desobedeció los parámetros artísticos y políticos de su época, para retratar la historia, los fenómenos sociales y políticos, destacó la belleza indígena, mestiza y campesina, pintó sobre los muros de las entidades y las escuelas, para enseñarnos el papel humanístico y político del arte en el desarrollo político de una sociedad. Sus muros hicieron reflexionar a los ciudadanos y motivó la movilización de los grupos para reivindicar la identidad mexicana.
Chagall incitó al respeto por el otro, a través de sus obras que recrean una cotidianidad diferente, al tiempo, invitó a la unidad, la humanidad y la tolerancia; sus pinturas promueven la reflexión sobre la consciencia para obedecer o desobedecer lo establecido. Rothko desea provocar emociones viscerales que cuestionen al individuo sobre sus actos, que lo lleven a pensar sobre su autonomía, que no lo dejen subordinar al consumismo y al asentimiento.

El artículo concluye con una breve referencia a Frida Kahlo, rebelde, desobediente, feminista, luchadora, crítica, inteligente, sobresaliente, fiel a sí misma y a sus ideas políticas, cuya vida y obra es una contribución incuestionable a la reivindicación femenina y la identidad latinoamericana. 


\section{Referencias bibliográficas}

Bartra, E. (1994). Frida Kablo: mujer, ideología, arte. Barcelona: Icaria.

Gombrich, E. H. (1995). La Historia del Arte. New York: Phaidon.

Herrera, H. (1983). Frida: una biografía de Frida Kablo. México D.F.: Planeta.

Ingo, F. W, \& Metzger, R. (2007). Chagall. Colonia: Taschen.

Kettenmann, A. (2006). Rivera. Colonia: Tashen.

Mena, M. M. (2002). Goya. Guía de Sala. Museo del Prado. Madrid: Fundación amigos del Museo-Alianza.
Platón, (1970). Apología de Sócrates, el Banquete, Fedro. Barcelona: Planeta.

Rose, M., \& Hagen, R. (2005). Goya. Colonia: Taschen.

Rivera, D. (mayo, 2007). Los murales del SEP. Revista Energía. 87(7). Recuperado de http:// www.fte-energia.org/E87/14.html

Schama, S. (2006). Documental "Power of Art" ("El Poder del Arte"). Reproducido por la $\mathrm{BBC}$ de Londres.

Thomas, F. (1994). Los estragos del amor. Bogotá: Universidad Nacional de Colombia.

Walther, I. (1999). Picasso. Colonia. Taschen. 